\title{
EFFECTS OF PRIMING WITH ASCORBIC ACID, L-CYSTEIN AND TRIACONTANOL ON GERMINATION OF RAPESEED (BRASSICA NAPUS L.)
}

\author{
Katalin MOLNÁR ${ }^{1,3^{*}}$, Béla BIRÓ-JANKA ${ }^{1}$, Imre-István NYÁRÁDI ${ }^{1}$, László FODORPATAKI ${ }^{2}$, \\ Bernadett-Enikő VARGA ${ }^{1}$, János BÁLINT ${ }^{1}$, Marcel-Matei DUDA ${ }^{3}$ \\ ${ }^{1}$ Department of Horticulture, Faculty of Technical and Human Sciences, Târgu-Mureş, Sapientia Hungarian \\ University of Transylvania, Cluj-Napoca, Romania \\ ${ }^{2}$ Hungarian Department of Biology and Ecology, Babeș-Bolyai University, \\ RO-400084 Cluj-Napoca, Romania \\ ${ }^{3}$ Faculty of Agriculture, University of Agriculture and Veterinary Medicine, Cluj-Napoca, Romania
}

\author{
*Correspondence: \\ Katalin MOLNÁR \\ molnarkati@ms.sapientia.ro
}

Received: 15 November 2020; Accepted: 19 December 2020; Published: 30 December 2020

\begin{abstract}
The germination of seed batches of two rapeseed (Brassica napus L.) hybrids ('Hybrirock' and 'Factor') were investigated in response to priming in aqueous solutions of ascorbic acid (10 $\mathrm{mM})$, L-cysteine $(10 \mathrm{mM})$ and triacontanol $(1 \mu \mathrm{M})$, respectively tap water (as control treatment). Investigations were focused on seed quality parameters, such as germination percentage, mean germination time, germination index, uniformity of germination, and seedling shoot and root growth. Germinated seeds were counted every 24 hours for a period of seven days, recording the final germination percentage (FGP), mean germination time (MGT), the coefficient of velocity of germination (CVG), germination rate index (GRI), germination index $(\mathrm{GI})$, uncertanty $(\mathrm{U})$, and synchrony $(\mathrm{Z})$. In a separate trial fresh shoot- and root length, respectively the dry weight of the shoots and roots were also determined after a 14 day period. Germination tests were performed to examine the quality of seeds in response to different priming treatments. The results demonstrated that priming improved the germination parameters of seeds of both hybrids. Furthermore, the use of ascorbic acid, L-cysteine and triacontanol also enhanced seedling growth. The results may be used to rank seed lots by vigor, and decisions can be made regarding planting potential of each seed lot.
\end{abstract}

Keywords: seed priming, germination, rapeseed, ascorbic acid, triacontanol, L-cystein.

\section{Introduction}

Rapeseed or canola (Brassica napus L.) belongs to the Brassicaceae family, and it is the second most important oilseed crop of the world, with an oil content of $40 \%$ (Bhuiyan et al., 2019). Rapeseed is used as an oil plant for nutritional and industrial purposes, and also as protein crop for animal feed (Nesi et al., 2008).
Plants are regularly exposed to various adverse environmental conditions. The abiotic stresses (drought, salinity, frost, and high temperatures) adversely affect the plant growth and productivity. High-quality seeds have the capability to germinate under adverse growing conditions (Ozbay, 2018). 
Rapid germination, high seed germination percentage, low mean germination time, respectively rapid and uniform seedling emergence are important aspects of canola production (Devaiah et al., 2007). Slow, delayed germination results in slow growth, and decreased number of normal seedlings (Walters, 1998).

Seed priming is an effective technique that can be used to enhance germination percentage and growth, and to achieve uniform plant stand and better yield in stress conditions (Kandil et al., 2018).

Poor and/or uneven germination followed by an unsynchronized seedling emergence are a major cause of losses in crop productions and yields (Dutta, 2018). Priming with nutrients is an innovative practice that holds positive influences in terms of enhanced nutrient supply. Plants with better nutrient supply possess greater potential to tolerate abiotic stress (Ashraf et al., 2018).

Priming with ascorbic acid, an important antioxidant and a promising priming agent (Jisha et al., 2013), showed significant effects on germination percentage, shoot- and root length, vigor index in case of rapeseed plants in drought conditions (Razaji et al., 2014).

Triacontanol, a long-chain aliphatic alcohol was found in 1933 (Ries et al.) as a component of the epicuticular waxes of alfalfa (Medicago sativa L.). Since then, its growth regulating effects have been shown in several greenhouse and field experiments and a number of attempts were made to clarify its mode of action as well. Growth stimulating effects of triacontanol in the micropropagation process of Melissa officinalis L. and fruit rootstocks are already demonstrated (Tantos et al., 1999).

Cellular redox state regulates important processes that mediate growth and development under stressful environment (Miller et al., 2009). Sulfur (S) is a key ameliorating agent for reducing the effect of heavy metals in plants. It is one of the essential micronutrients that regulate photosynthesis under normal and stress condition (Saha et al., 2019). Sulfur forms the basic structural component for certain amino acids e.g cysteine and methionine (Khan et al., 2014). Seed priming with cysteine alleviated injury due to gamma radiation, and caused more conspicuous effects in the elongation of primary roots (Reddy and Smith, 1978).

Many experiments investigated the effects of seed treatments on germination parameters. Ansari et al. (2013) and Seiadat et al. (2012) reported that priming improves germination parameters in many crops.

The result is measured in terms of the extent to which seeds have germinated. But not just the final germination percentage attained is of great interest, but also the mean germination time, germination index, germination rate index, coefficient of velocity of germination, synchrony, and uncertainty are often used to judge the agronomic relevance of treatments (Al-Mudaris, 1998).

Various parameters for measuring or estimating germination speed have been developed. Mean germination time can be used as an indicator of seed vigor in canola (Amirmoradi and Feizi, 2017). The germination index (GI) emphasizes on both the percentage of germination and its speed. A higher GI value denotes a better percentage and rate of germination (Kader, 2005). The velocity of germination (CVG) coefficient indicates the rapidity of germination (Al-Mudaris, 1998). Higher germination rate index (GRI) values indicate higher and faster germination (Kader, 2005).

Based on germination characters and seedling growth parameters it can be concluded which varieties are more tolerant, under salinity stress. Seedling growth parameters as shoot and root length, fresh weights, and dry weights, were affected significantly by the interaction 
between cultivars and salinity concentrations (Kandil et al., 2016).

The aim of the study was to test priming with ascorbic acid, L-cysteine, and triacontanol solution, at very low (millimolar/ppm) concentration, on germination and seedling growth processes of two rapeseed hybrids in order to optimize the rapeseed plants growth.

\section{Materials and Methods}

The experiment was performed in the laboratory of Sapientia Hungarian University of Transylvania, Faculty of Technical and Human Sciences, Târgu-Mureș, in 2019.

\subsection{Seed materials}

Seeds of two rapeseed (Brassica napus L.) hybrids, (Hybrirock and Factor) provided by KWS Romania were used in this study.

\subsection{Priming}

Priming was made with the following substances:

1. Ascorbic acid $\geq 99.0 \%$ (ASA) was purchased from VWR,

2. L-Cysteine $97.0 \%$ (L-cyst) was purchased from Merck,

3. Triacontanol $2.5 \%$ (Tria) was purchased from Nutri-Tech-Solution.

During the experiment batches of 25 seeds each, in four replications were used. The seeds were immersed prior to the start of the germination trial for 24 hours at $24{ }^{\circ} \mathrm{C}$ in the priming solutions of ascorbic acid $(10 \mathrm{mM}), \mathrm{L}-$ cysteine $(10 \mathrm{mM})$ or triacontanol $(1 \mu \mathrm{M})$. Seeds of the control treatment were submersed in tap water.

\subsection{Germination test}

After priming, the seed cohorts were placed in Linhardt vessels in laboratory conditions $\left(20^{\circ} \mathrm{C}, 75 \%\right.$ relative humidity, $16 \mathrm{~h}$ photoperiod), according to national germination standards (SR 1634/ 1999). To determine the germination indices, observations were performed every 24 hours for a seven day period. The germination indices and seed growth including final germination percentage (FGP), mean germination time (MGT), the coefficient of velocity of germination $(\mathrm{CVG})$, germination rate index (GRI), germination index (GI), uncertanty (U), and synchrony $(Z)$ were calculated.

\subsection{Seedling growth rate}

Twenty-five seeds per each replication were placed in Linhardt vessels under the same conditions $\left(20^{\circ} \mathrm{C}, 75 \%\right.$ relative humidity, $16 \mathrm{~h}$ photoperiod) for a 14 days period. At the end of the growth period the seedlings shoot and root lengths were measured using a caliper and expressed in $\mathrm{mm}$.

Fresh and dry shoot and root mass were weighed using an analytical balance, and expressed in g. The shoots and roots of the seedlings were cut from the axis and were dried in an oven at $75^{\circ} \mathrm{C}$ for $48 \mathrm{~h}$.

\subsection{Methods of calculation of germination parameters}

Seven different germination parameters were assessed. The methodology of calculations of parameters (2), (3), (4), (5) followed Al-Mudaris (1998), (6) and (7) Ranal et al. (2009), and (1) followed Aravid et al. (2020).

(1) Final germination percentage (FGP)

$F G P=\frac{N g}{N t} x 100$

$\mathrm{Ng}=$ Number of germinated seeds

$\mathrm{Nt}=$ Total number of seeds

(2) Mean germination time (MGT)

$\mathrm{MGT}=\Sigma \mathrm{f} \cdot \mathrm{x} / \Sigma \mathrm{f}$

$\mathrm{f}=$ Seed germinated on day $\mathrm{x}$

(3) Coefficient of velocity of germination $(\mathrm{CVG})$

$\mathrm{CVG}=100 \times \Sigma \mathrm{Ni} / \Sigma \mathrm{NiTi}$

$\mathrm{Ni}=$ Number of germinated seeds per day 
$\mathrm{Ti}=$ Number of days from the start of the experiment

(4) Germination rate index (GRI)

$\mathrm{GRI}=\mathrm{G} 1 / 1+\mathrm{G} 2 / 2+\ldots .+\mathrm{Gx} / \mathrm{x}$

$\mathrm{G} 1$ is the germination percentage on day $1, \mathrm{G} 2$ is the germination percentage at day 2; and so on

(5) Germination index (GI)

$$
\mathrm{GI}=(7 \times \mathrm{N} 1)+(6 \times \mathrm{N} 2)+\ldots .+(1 \times
$$

N7)

$\mathrm{N} 1, \quad \mathrm{~N} 2 \quad \ldots \mathrm{N} 7$ is the number of germinated seeds on the first, second and subsequent days until 7th day: 7, 6... and 1 are weights given to the number of germinated seeds on the first, second and subsequent days, respectively.

(6) Uncertanty (U)

$$
U=-\sum_{i=1}^{k} f i \log 2 f i
$$

Where, $f i$ is the relative frequency of germination (estimated as $f_{i}=\frac{N i}{\sum_{i=1}^{k} N i}$ ),

$\mathrm{Ni}$ is the number of seeds germinated on the ith time interval, and $k$ is the total number of time intervals

7. Synchrony (Z)

$$
Z=\frac{\sum_{i=1}^{k} N i, 2}{C \sum N i, 2}
$$

Where, $\mathrm{CNi}, 2$ is the partial combination of the two germinated seeds from among $\mathrm{Ni}$, the number of seeds germinated on the $i$ th time interval (estimated as $C N i, 2=\frac{N i(N i-1)}{2}$ ), and $\mathrm{C} \Sigma \mathrm{Ni}, 2$ is the partial combination of the two germinated seeds from among the total number of seeds germinated at the final count, assuming that all seeds that germinated did so simultaneously.

\subsection{Statistical Analyses}

The SPSS software was used to perform a descriptive analysis based of means of each germination index. The data obtained were subjected to one-way Analysis of Variance (ANOVA). After assessing the distribution of the datasets, post-hoc tests were run, namely Tukey pairwise test in the case of normally distributed data and Mann-Whitney pairwise test, in the case of non-normally distributed data $(p \leq 0.05)$.

\section{Results and discussions}

In the majority of cases the final germination percentage (FGP) of both hybrids was improved due to priming (Table 1).

Positive effects were observed on 'Factor' hybrid seeds in case of treatments with ASA and L-cyst, while treatment with Tria had negative effect on the seeds, although the differences were not significant. The seeds of 'Hybrirock' variety also responded positively to priming, the FGP having higher values compared to the control. The differences were significant in case of ASA and L-cyst ( $p \leq 0.05)$.

The mean germination time (MGT) decreased in both hybrids in response to priming, excepting 'Factor' hybrid treated with L-cyst, where the MGT value increased compared to the control (Table 1). 'Factor' hybrid had higher MGT values than 'Hybrirock' and also, the differences among treatments had higher variation. The lowest (ASA treatment) and highest (L-cyst) values of MGT parameter varied significantly $(p \leq 0.05)$ for 'Factor' seeds. 
Table 1. The results of one-way ANOVA analysis and the Tukey post-hoc test, (in the case of the * Mann-Whitney test) on the germination parameters; different letters denote significant differences at $p \leq 0.05$.

\begin{tabular}{|c|c|c|c|c|c|c|c|c|}
\hline Hybrid & Treatment & $\begin{array}{c}\text { FGP } \\
\%\end{array}$ & $\begin{array}{c}\text { MGT * } \\
(\text { day })\end{array}$ & GI & CVG* & $\begin{array}{c}\text { GRI } \\
\text { (\%/day) }\end{array}$ & $\underset{\text { (bit) }}{\mathbf{U}}$ & $\mathbf{Z}$ \\
\hline \multirow{5}{*}{ 'Factor' } & ASA & $99^{a}$ & $1.202^{\mathrm{a}}$ & $118.75^{\mathrm{a}}$ & $83.83^{a}$ & $23.41^{\mathrm{a}}$ & $0.4375^{b}$ & $0.8435^{\mathrm{a}}$ \\
\hline & L-cyst & $96^{\mathrm{a}}$ & $1.532^{\mathrm{b}}$ & $106.25^{\mathrm{b}}$ & $66.21^{\mathrm{b}}$ & $19.70^{\mathrm{b}}$ & $1.1300^{\mathrm{a}}$ & $0.5285^{b}$ \\
\hline & Tria & $93^{a}$ & $1.315^{\mathrm{ab}}$ & $109.75^{\mathrm{ab}}$ & $79.28^{\mathrm{ab}}$ & $21.80^{\mathrm{ab}}$ & $0.4350^{b}$ & $0.8432^{a}$ \\
\hline & Control & $94^{\mathrm{a}}$ & $1.365^{\mathrm{ab}}$ & $108.75^{\mathrm{ab}}$ & $74.13^{\mathrm{ab}}$ & $20.92^{\mathrm{ab}}$ & $0.8187^{\mathrm{ab}}$ & $0.6810^{\mathrm{ab}}$ \\
\hline & Treatment & FGP \% & $\begin{array}{c}\text { MGT * } \\
(\text { day })\end{array}$ & GI & CVG* & $\begin{array}{c}\text { GRI } \\
\text { (\%/day) }\end{array}$ & $\underset{\text { (bit) }}{\mathbf{U}}$ & $\mathbf{Z}^{*}$ \\
\hline \multirow{4}{*}{ 'Hybrirock' } & ASA & $99.5^{\mathrm{ab}}$ & $1.04^{\mathrm{ab}}$ & $124.50^{\mathrm{a}}$ & $96.36^{\mathrm{ab}}$ & $24.68^{a}$ & $0.121^{\text {ab }}$ & $0.9600^{a b}$ \\
\hline & L-cyst & $98^{\mathrm{ab}}$ & $1.08^{\mathrm{ab}}$ & $123.00^{\mathrm{ab}}$ & $93.01^{\mathrm{b}}$ & $24.38^{\mathrm{a}}$ & $0.148^{\mathrm{ab}}$ & $0.9207^{\mathrm{ab}}$ \\
\hline & Tria & $99^{b}$ & $1.00^{\mathrm{a}}$ & $123.70^{\mathrm{ab}}$ & $100^{a}$ & $24.75^{\mathrm{a}}$ & $0.0142^{b}$ & $1.0000^{\mathrm{a}}$ \\
\hline & Control & $90^{\mathrm{b}}$ & $1.19^{\mathrm{b}}$ & $108.25^{b}$ & $86.48^{\mathrm{b}}$ & $21.27^{b}$ & $0.471^{\mathrm{a}}$ & $0.8420^{b}$ \\
\hline
\end{tabular}

Note: FGP-final germination percentage; MGT-mean germination time; GI-germination index; CVG-coefficient of velocity of germination; GRI-germination rate index; U-uncertanty; Z-synchrony

Tria and Control treatments had similar values and no significant differences were observed. All of the used substances have reduced the MGT of 'Hybrirock' seeds but only seeds treated with Tria differed significantly from untreated seeds. In case of ASA and L-cyst treated seeds no significant differences were found regarding the MGT compared to control.

The seeds of rapeseed varieties responded differently to priming regarding the germination index (GI). The used substances increased the GI parameter of 'Hybrirock' seedbatches in a more pronounced manner than in the case of 'Factor' variety. 'Factor' seeds had the highest GI values when treated with ASA, followed by Tria and the Control treatment, while seeds of L-cyst presented the lowest GI values. Among ASA and L-cyst treatments there were statistically significant differences $(p \leq 0.05)$. All treatments resulted in higher GI values for 'Hybrirock' variety compared to the untreated batch. Furthermore the ASA and Tria treatments values differed significantly from the control batch (Table 1).

'Hybrirock' variety had higher values than 'Factor' also regarding the CVG parameter. Seeds treated with L-cystein had the lowest
CVG in the case of 'Factor' hybrid, followed by the untreated seed batch, seeds treated with Tria and ASA, respectively. There were statistically significant differences among the lowest (L-cyst) and highest (ASA) values. 'Hybrirock' seeds reacted differently to the different treatments. In this case the untreated seeds were characterized with the lowest CVG values, followed by L-cyst, ASA and finally Tria treatments. The results with Tria were significantly different from the untreated seeds and those of L-cyst treatment (Table 1).

'Hybrirock' variety also had superior germination rate index (GRI) compared to 'Factor' variety. 'Factor' seeds responded negatively to L-cyst treatment, the GRI values of this treatment being lower than those of the untreated seeds. On the contrary, with Tria and ASA superior results were obtained compared to control treatment. ASA treatment resulted in significantly higher GRI values compared to those of L-cyst treatment. In the case of 'Hybrirock' variety, all of the used substances had positive effect on the GRI parameter. The results of the three treatments presented higher variation, but all of them differed significantly from the control seeds (Table 1). 
Table 2. The results of the one-way ANOVA analysis and the Tukey post-hoc test (in the case of the * Mann-Whitney test) on seedling growth parameters of 'Hybrirock' variety, different letters denote significant differences at $p \leq 0.05$.

\begin{tabular}{|c|l|c|c|c|c|c|c|}
\hline Hybrid & Treatment & SL $(\mathbf{m m})$ & $\begin{array}{c}\text { RL } \\
(\mathbf{m m})\end{array}$ & $\begin{array}{c}\mathbf{S F W}^{*} \\
(\mathbf{g})\end{array}$ & $\begin{array}{c}\mathbf{R F W}^{*} \\
(\mathbf{g})\end{array}$ & $\begin{array}{c}\mathbf{S D W}^{*} \\
(\mathbf{g})\end{array}$ & $\begin{array}{c}\text { RDW }^{*} \\
(\mathbf{g})\end{array}$ \\
\hline \multirow{4}{*}{ 'Hybrirock' } & ASA & $22.99^{\mathrm{b}}$ & $48.95^{\mathrm{a}}$ & $0.499^{\mathrm{ab}}$ & $0.245^{\mathrm{a}}$ & $0.085^{\mathrm{a}}$ & $0.0165^{\mathrm{a}}$ \\
\cline { 2 - 8 } & L-cyst & $22.61^{\mathrm{bc}}$ & $38.61^{\mathrm{b}}$ & $0.368^{\mathrm{b}}$ & $0.167^{\mathrm{ab}}$ & $0.062^{\mathrm{b}}$ & $0.0082^{\mathrm{b}}$ \\
\cline { 2 - 8 } & Tria & $31.48^{\mathrm{a}}$ & $41.32^{\mathrm{b}}$ & $0.531^{\mathrm{a}}$ & $0.226^{\mathrm{ab}}$ & $0.080^{\mathrm{ab}}$ & $0.0117^{\mathrm{ab}}$ \\
\cline { 2 - 8 } & Control & $18.97^{\mathrm{c}}$ & $24.90^{\mathrm{c}}$ & $0.401^{\mathrm{ab}}$ & $0.128^{\mathrm{b}}$ & $0.069^{\mathrm{ab}}$ & $0.0092^{\mathrm{b}}$ \\
\hline
\end{tabular}

Note: SL- shoot length, RL- root length; SFW- shoot fresh weight; RFW- root fresh weight ; SDW- shoot dry weight; RDW - root dry weight

The uncertainty (U) values of 'Factor' variety are at least two times higher than the values of 'Hybrirock' variety. L-cystein had negative effects on 'Factor' seeds, raising their $\mathrm{U}$ values, while ASA and Tria treatments decreased the parameter, compared to the control seeds. The differences between Lcystein, respectively ASA and Tria treatments were statistically significant $(p \leq 0.05)$. 'Hybrirock' seeds reacted in a positive manner to all treatments, thus the $\mathrm{U}$ value decreased at least three folds (Table 1).

The synchrony $(\mathrm{Z})$ of germination was also higher in 'Hybrirock', and lower in 'Factor' variety. As a result of priming in L-cyst solution, the $\mathrm{Z}$ value of 'Factor' hybrid decreased, on the other hand, priming in Tria, or ASA solutions increased the $\mathrm{Z}$ value of the seed cohorts. Statistically significant differences can be spotted among the results of L-cyst, respectively Tria and ASA treatments. 'Hybrirock' seeds reacted positively to all substances, with Tria treatment having the most positive effect, resulting in significant differences compared to the untreated seeds (Table 1).

Due to an unexpected fungal contamination of the dishes containing the seeds of 'Factor' variety, the results of shoot and root biometrics are not presented.

Priming had a positive effect on shoot length of 'Hybrirock' seedlings. Tria treatments produced the highest shoot elongation and shoot fresh weight (SFW), the results being significantly different of those of control treatment. Also all of the priming substances had positive effect on root fresh (RFW) and dry weight (RDW) excepting L-cyst. In this case the most remarkable results were obtained in seed cohorts treated with ASA, followed by Tria. There were statistically significant differences among ASA, respectively Tria and L-cyst group, and the control treatment (Table 2). The results regarding the dry weights of shoots (SDW) and roots (RDW) of the seedlings were somewhat similar. Seed batches treated with L-cystein have developed organs with smaller dry weight than the untreated seeds. On the contrary seeds treated with Tria and ASA are characterized with superior dry shoot and root weights. There are significant differences in both cases, namely between the results of L-cyst and ASA treatments in the case of SDW, respectively between L-cysttreated and untreated and ASA treated seeds (Table2).

Altogether it can be concluded that to maximize seedling establishment and germination parameters in 'Factor' and 'Hybrirock' hybrids, priming with ASA or Tria are recommended.

\section{Conclusions}

The results of the study show that canola seeds respond differently to the priming substances. In most of the cases the 
germination and seedling growth parameters were increased compared to the control due to priming.

Overall, it can be said that seed priming with ascorbic acid performed better in 'Factor' rapeseed hybrid, by indicators MGT, GI, CVG, GRI, and Z. Triacontanol priming produced also good results, while L-cysteine treatments results were weaker compared to the control.

'Hybrirock' seeds responded better to triacontanol treatments, followed by priming with ascorbic acid and L-cystein.

Results concerning seedling biomass production indicate that the average shoot and root length were lowest in the untreated seeds, while shoot and root dry weight gain was the lowest in the L-cyst treated group of seeds of 'Hybrirock' variety.

The seed priming can improve the seeds germination parameters and induce early, synchronized and healthier crop stand. Priming with ascorbic acid, L-cysteine and triacontanol could also invigorate the seeds at early seedling stage.

Further experiments are required to clarify the effects of the above mentioned substances.

\section{Conflict of Interest}

The authors declare that the research was conducted in the absence of any commercial or financial relationships that could be construed as a potential conflict of interest.

\section{Acknowledgments}

This work was supported by the Collegium Talentum Programme of Hungary.

\section{References}

1. Al-Mudaris M (1998) Notes on various parameters recording the speed of seed germination. In: Der Tropenlandwirt Journal of Agriculture in the Tropics and Subtropics, Vol 99, No2, pp 147-154.
2. Amirmoradi S, Feizi H (2017) Can mean germination time predict seed vigor of canola (Brassica napus L.) seed lots? Acta Agrobot. 70(4):1729. https://doi.org/10.5586/aa.1729

3. Ansari O, Sharif-Zadeh F, Moradi A, Azadi MS, Younesi E (2013) Heat shock treatment can improve some seed germination indexes and enzyme activity in primed seeds with gibberellin of mountain rye (Secale montanum) under accelerated aging conditions. Cercet. Agron. Moldova 156 (4):21-30.

4. Aravind J, Vimala Devi S, Radhamani J, Jacob S R, and Kalyani Srinivasan (2020) germinationmetrics: Seed Germination Indices and Curve Fitting. $\mathrm{R}$ package version 0.1.4.9000

https://github.com/aravind-

j/germinationmetricshttps://cran.rproject.or $\mathrm{g} /$ package $=$ germinationmetrics

5. Ashraf MA, Akbar A, Askari SH, Iqbal M, Rasheed R, Hussain I (2018) Recent Advances in Abiotic Stress Tolerance of Plants Through Chemical Priming: An Overview. In: Rakshit A., Singh H. (eds) Avances in Seed Priming. Springer, Singapore. https://doi.org/10.1007/978981-13-0032-5_4

6. Bhuiyan TF, Ahamed KU, Nahar K, Al Mahmud J, Bhuyan MB, Anee TI, Fujita M, Hasanuzzaman M (2019). Mitigation of PEG-induced drought stress in rapeseed (Brassica rapa L.) by exogenous application of osmolytes. Biocatal. Agric. Biotechnol. 20:1-10. https://doi.org/10.1016/j.bcab.2019.101197

7. Saha B, Chowardhara B, Kar S, Devi SS, Awasthi JP, Moulick D, Tanti B, Panda SK (2019) Advances in Heavy Metal-Induced Stress Alleviation with Respect to Exogenous Amendments in Crop Plants. In: Hasanuzzaman M., Fotopoulos V. (eds) Priming and Pretreatment of Seeds and 
Seedlings. Springer, Singapore. https://doi.org/10.1007/978-981-13-86251_15

8. Deviah SP, Pan X, Hong Y, Roth M, Welti R, Wang X (2007) Enhancing seed quality and viability by suppressing phospholipase D in Arabidopsis. The Plant J. 50: 950-957.

9. Dutta P (2018) Seed Priming: New Vistas and Contemporary Perspectives. In: Rakshit A., Singh H. (eds) Advances in Seed Priming. Springer, Singapore. https://doi.org/10.1007/978-981-13-00325_1

10. Jisha KC, Vijayakumari K, Puthur JT (2013) Seed priming for abiotic stress tolerance: an overview. Acta Physiol Plant 35(5):1381-1396. https://doi.org/10.1007/s11738-012-1186-5

11. Kader M. A (2005) A comparison of seed germination calculation formulae and the associated interpretation of resulting data. Journal \& Proceedings of the Royal Society of New South Wales 138:65-75.

12. Kandil AAEN, Sharief AES, Botabaah AKD (2018) Effect of antioxidants and salinity stress on seedling parameters of some wheat cultivars. Res. J. Seed Sci. 11:12-21.

13. Kandil AA, Sharief AE, Kasim MF (2016) Germination characters as affected by seed priming of some safflower cultivars under salinity stress. Int. J. Agron. Agric. Res. 9:65-80.

14. Khan NA, Khan MI, Asgher M, Fatma M, Masood A, Syeed S (2014) Salinity tolerance in plants: revisiting the role of sulfur metabolites. J Plant Biochem Physiol 2(120):2.

15. Nesi N, Delourme R, Bregeon M, Falentin C, Renard M (2008) Genetic and molecular approaches to improve nutritional value of Brassica napus L. seed. C R Biol 331:763771.
16. Ozbay N (2018) Studies on Seed Priming in Pepper (Capsicum annuum L.). In: Rakshit A., Singh H. (eds) Advances in Seed Priming. Springer, Singapore. https://doi.org/10.1007/978-981-13-00325_12

17. Ranal MA, Garcia de Santana D, Ferreira WR, Mendes-Rodrigues C (2009) Calculating germination measurements and organizing spreadsheets. In: Revista Brasiliera Botanica 32, pp 849-855.

18. Razaji A, Farzanian M, Sayfzadeh S (2014) The effects of seed priming by ascorbic acid on some morphological and biochemical aspects of rapeseed (Brassica napus L.) under drought stress condition. Int J Biosci 4(1):432-442.

19. Reddy CS, Smith JD (1978) Effects of delayed post treatment of gamma-irradiated seed with cysteine on the growth of Sorghum bicolor seedlings. Environ Exp Bot 18(4):241-243. https://doi.org/10.1016/00988472(78)90050-3

20. Seiadat SA, Moosavi A, Sharafizadeh M (2012) Effect of seed priming on antioxidant activity and germination characteristics of Maize seeds under different aging treatments. Research Journals of Seed Scienc 5(2):51-62.

21. Tantos Á, Mészáros A, Kissimon J, Horváth G, Farkas T (1999) The effect of triacontanol on micropropagation of balm, Melissa officinalis L. Plant Cell Rep. 19:88-91.

22. Walters, C (1998) Understanding the mechanisms and kinetics of seed aging. Seed. Sci. Res. 8:223-244.

23. *** SR (Standard Român) 1634, (1999) Seeds for sowing. Germination test 